\title{
Bullying Terhadap Guru Wujud Hilangnya Batasan Siswa Ditinjau Dari Sudut Pandang Intelek Dan Kehendak Manusia
}

Oleh:

\author{
Thomas Aquinas Vikrasta Candra Dewa
}

Universitas Katholik Widya Mandala Madiun

\begin{abstract}
Bullying merupakan cara atau perilaku manusia menyakiti orang lain dengan cara kekerasan, bisa berupa kekerasan fisik ataupun secara ucapan. Pada dasarnya tindakan bullying dibedakan menjadi tiga bentuk, diantaranya berupa kekerasan fisik, psikologis dan ucapan (lisan). Maraknya bullying terhadap guru sebagai cerminan buram dunia pendidikan. Bullying disebabkan oleh kepribadian seseorang, pendapat Carl Gustav Jung mengenai kepribadian secara garis besar membahas tingkah laku manusia yang ditentukan berdasarkan kausalitas dan juga tujuan-tujuan serta aspirasi. Manusia memiliki kebebasan dalam hal apapun, kebebasan tersebut tetap ada ukuranya ditinjau dari spiritualistik maupun materialistik. Diperlukan beberapa pihak yang terlibat demi terwujudnya kepribadian yang lebih baik.
\end{abstract}

Keywords: bullying, kepribadian, kehendak

\section{Pendahuluan}

Tindakan bullying sangat marak dilakukan pada tahun belakangan ini, awal terjadinya bisa dipicu oleh beberapa faktor, misalnya ketidaksukaan antara seseorang terhadap tingkah laku, bisa berupa sifat iri karena seseorang telah berhasil dan bisa dipicu karena alasan balas dendam. Korban yang terkena bullying biasanya akan terganggu secara mental, psikologis maupun fisiknya. Mereka akan merasa bahwa dirinya dikucilkan, merasa bahwa tidak ada lagi orang yang peduli terhadapnya, bahkan korban akan merasakan minder sehingga segala potensi yang ada pada diri seseorang akan terbunuh dengan pelan-pelan. Sama halnya bullying dapat dikatakan sebagai tindakan pembunuhan karakter terhadap seseorang, jika tindakan bullying tersebut dilakukan secara terus-menerus kemungkinan besar korban akan depresi dengan sendirinya. 
Pada dasarnya tindakan bullying dibedakan menjadi tiga bentuk, diantaranya berupa kekerasan fisik, psikologis dan ucapan (lisan). Bentuk kekerasan fisik biasanya dilakukan dengan memukul, menendang dan merusak sesuatu benda yang dimiliki korban. Dengan tindakan ini, korban akan dirugikan secara kesehatan fisik yang dampaknya menimbulkan luka ditubuh, sakit dan cedera badan. Bentuk kekerasan psikologis pada dasarnya dilakukan dengan cara ancaman terhadap korban, kecaman, pencemaran nama baik dan intimidasi. Cara demikian menyebabkan kondisi psikologis korban menjadi terganggu. Sedangkan bentuk kekerasan secara ucapan berupa ucapan yang tidak pantas, panggilan nama orang tua dan berupa sindiran keras yang ditujukan kepada korban bullying.

Tindakan bullying biasanya dilakukan oleh kelompok atau individu yang lebih kuat dengan cara menindas yang lebih lemah, pelaku bullying biasanya menganggap dirinya paling hebat, sehingga cara penindasannya menyebabkan sebagian korban yang lemah akan merasa terbebani bahkan sampai trauma. Kondisi yang demikian membuat dewasa ini semakin miris mendengarnya, ditambah lagi kasus bullying yang kerap terjadi beberapa tahun terakhir ini semakin tidak wajar. Biasanya kasus bullying yang sering terjadi adalah dilingkup sekolah yang konteknya siswa dengan siswa, atau atas dasar batas umur antara pelaku dan korban tidak terpaut jauh.

Berbeda lagi dengan kasus yang ada di salah satu SMP di Gresik, Jawa Timur. Terdapat seorang siswa yang menantang gurunya dengan unsur sengaja merokok di hadapan gurunya tersebut, siswa tersebut ditegur oleh gurunya dengan maksud untuk mengingatkan bahwa tindakan merokok tersebut tidaklah benar dilakukan di area sekolah. Namun yang terjadi adalah siswa tersebut malah menantang gurunya untuk berkelahi bahkan sampai berani mencekik leher gurunya, tetapi dengan bijak guru tersebut tidak memberikan sedikitpun perlawanan terhadap siswanya. Kejadian itu direkam oleh siswa yang berada dilokasi tersebut dan diunggah ke media sosial dengan niat iseng, tapi setelah unggahan tersebut berada di media sosial justru menjadi trending topik pada saat itu dengan jumlah penontonton sampai pada angka jutaan. Dengan media sosial, 
kasus tersebut dapat dengan mudah diakses atau dilihat dari berbagai macam usia tanpa ada batasan apapun, kemudahan tersebut dapat membawa pengaruh buruk bagi penonton yang memiliki tingkat kematangan dibawah umur, karena perilaku yang dicerminkan oleh siswa di salah satu SMP Gresik sangat tidak etis dan tidak pantas dicontoh.

Berdasarkan kasus yang dijelaskan diatas, penulis hendak menyoroti maraknya bullying terhadap guru sebagai cerminan buram dunia pendidikan dengan menggunakan aliran determinisme, sesuai pendapat Carl Gustav Jung yaitu manusia bergantung pada hukum yang ada. Harapan dari penulisan ini adalah untuk menyadari bahwa manusia hidup itu ada atauran yang harus tetap dibudayakan sebagai pedoman hidup, walaupun dewasa ini kita tengah hidup di era modern, dimana segala perilaku baik buruknya seseorang dapat dengan cepat diketahui oleh banyak orang.

\section{Hubungan Antara Kepribadian dan Kebebasan Yang Teratur}

Menurut Kamus Besar Bahasa Indonesia pengertian manusia adalah makhluk yang berakal budi, secara garis besar artinya mampu menguasai makhluk lain atau lebih istimewa daripada makhluk lain. Manusia termasuk dalam makluk sosial yang hakekatnya membutuhkan sesamanya untuk kelangsungan hidupnya dan tidak bisa hidup secara sendiri-sendiri. Dalam kehidupan manusia tentunya ada aturan-aturan atau undang-undang yang tujuannya mengarah kepada pedoman hidup yang baik. Dengan undang-undang, kehidupan manusia menjadi lebih tertib, terarah dan mempunyai batasan untuk bertindak.

Cakupan yang dilindungi oleh undang-undang di Negara Indonesia sangatlah luas dan merata khususnya di bidang profesi kepada seluruh lapisan masyarakat, salah satunya adalah profesi guru dan tenaga pengajar, sesuai dengan kasus yang dijelaskan pada pendahuluan di atas. Berdasarkan pasal 39 ayat (3) Undang-Undang Nomor 14 Tahun 2005 tentang Guru dan Dosen yang menyebutkan bahwa perlindungan hukum mencakup dari tindak kekerasan, 
ancaman, perlakuan diskriminatif, intimidasi atau perlakuan tidak adil dari pihak peserta didik, orang tua peserta didik, masyarakat, birokrasi atau pihak lain.

Undang-undang yang dibuat mengarah untuk ketentraman dalam menjalani kehidupan, namun pada dasarnya manusia memiliki karakter yang berbeda-beda di setiap kepala. Keberanekaragaman cara berpikir dalam memaknai kehidupan secara baik dan benar menjadikan upaya bagi setiap individu untuk mencari keberadaan bahwa hidup yang ada aturan menjadikan manusia menjadi beradab, seperti halnya perilaku manusia yang telah diperbuat mencerminkan sebuah kepribadian yang dimiliki setiap individu.

Pendapat Carl Gustav Jung mengenai kepribadian secara garis besar membahas tingkah laku manusia yang ditentukan berdasarkan kausalitas dan juga tujuan-tujuan serta aspirasi. Kepribadian tersebut tidak dipengaruhi oleh masa lalu, tetapi juga pandangan serta harapan tentang masa depan. Struktur kepribadian tersebut terdiri dari kesadaran, ketidaksadaran pribadi, ketidaksadaran kolektif, persona dan lain sebagainya. Teori yang ditekankan oleh Carl Gustav Jung dipandang sebagai teori psikoanalitik yang mengarah kepada kepribadian manusia.

Manusia memiliki kebebasan dalam hal apapun, suatu keputusan saat manusia melakukan kebebasan yang didasarkan bahwa mereka harus tetap tunduk pada apa yang telah diputuskan untuk mengetahui bahwa batasan kebebasan tersebut tetap ada ukuranya. Hal ini sesuai dasar yang dipakai berdasarkan subjek manusia itu tidak bebas. Dari sudut pandang secara spiritualistik dijelaskan bahwa kebebasan manusia ternyata diarahka pada hal yang baik, meskipun pada nyatanya arah kebebasan masih banyak yang kurang terarah tapi tetap ada batasannya. Berbeda dengan sudut pandang materialistik, dalam hal ini dijelaskan bahwa manusia tersebut tidak bebas karena seluruh tindakan yang akan dilakukan sudah diatur kepada keharusan alamiah, yaitu dengan mengikuti hukum materi. 


\section{Keterlibatan Antara Peran Guru, Siswa dan Orang Tua}

Ulasan ini membahas tentang kasus maraknya bullying terhadap guru sebagai cerminan buram dunia pendidikan. Hal ini menjadikan dewasa ini merasa miris dengan perbuatan yang dilakukan oleh siswa di salah satu SMP Gresik. Bagaimana tidak miris, guru yang seharusnya dihormati oleh siswa sebagai pahlawan tanpa tanda jasa justru dihadapkan oleh sikap kurang terpuji dari siswanya. Dalam berita yang memuat kasus tersebut terlihat bahwa Guru yang menjadi korban bullying oleh siswanya tersebut tidak memberikan perlawanan sedikitpun walaupun secara sikap dan tingkah laku siswanya sudah bisa dibilang melewati batas.

Ketika batasan tersebut sudah tidak ada maka timbulah kejadian seperti kasus ini, hilangnya pembedaan antara teman yang lebih kecil, teman sebaya dan orang yang lebih tua. Meskipun kehidupan anak muda sekarang berada di jaman generasi milenial tapi tetaplah tata krama harus tetap dijunjung, sikap menghargai kepada yag lebih tua dan sesama tentunya memberikan warna tersendiri dalam kehidupan manusia sebagai mahkluk sosial. Dalam realita kehidupan yang terus berputar tetaplah peran orang lain diperlukan, misalnya di lingkungan sekolah. Guru diperlukan siswa untuk mendidik atau memberikan pengetahuan kepada siswanya, dilingkungan sekolah tentunya terdapat aturan-aturan yang harus ditaati oleh seluruh warga sekolah.

Perilaku bullying terhadap guru bisa terjadi mungkin dikarenakan remaja dijaman milenial cenderung memiliki pola pikir yang pendek, sehingga ketika dihadapkan pada suatu permasalahan mereka kurang bijak menyikapinya, ditambah lagi pada usia remaja cenderung meiliki emosional yang labil. Dalam menjalankan aktivitasnya sehari-hari mereka tentu memiliki banyak waktu bersosial di lingkungan sekolah, sehingga pelapiasan kekesalan kemungkinan besar mereka luapkan di lingkungan sekolah tersebut.

Melihat kasus tersebut, terdapat dua sudut pandang yang disoroti yaitu antara guru yang menjadi korban bullying dan siswa sebagai pelaku bullying. 
Guru tersebut memberikan contoh yang baik kepada siswa yang berada di lingkup kejadian, tidak ada sedikitpun perlawanan yang dilakukan, walaupun secara undang-undang guru tersebut dilindungi. Guru berhak menegur siswa yang dirasa melanggar peraturan-peraturan sekolah, asalkan teguran tersebut tidak bersifat kekerasan. Perlu diadakan pendekatan yang lebih kepada siswa-siswa yang diajar, disini peran guru diperlukan supaya antara siswa dan guru dapat saling memahami.

Cara mengajar guru pun juga harus disesuaikan dengan kondisi yang sekarang, karena dengan cara mengajar yang baik dan benar dapat menambah rasa nyaman siswa dalam lingkup kelas. Guru pun juga harus terbuka dan mampu menjadi pendengar yang baik bagi siswanya, hal ini dimaksudkan ketika siswa berada dalam kondisi terdapat masalah dapat teridentifikasi. Ketika sudah terjadi hal demikian, peran wali kelas adan guru Bimbingan Konseling yang ada disekolah juga harus berjalan efektif dalam melayani siswa yang bermasalah sehingga psikologis siswa serta emosionalnya dapat terlayani dengan sebaik mungkin.

Siswa yang menjadi bagian dari anggota sekolah juga harus memiliki keterbukaan ketika dihadapkan permasalahan berkaitan dengan sistem pengajaran guru, konflik dengan teman disekolah dan permasalahan yang dapat mengganggu konsentrasi belajar disekolah. Secara tingkah laku, ketika dilingkungan sekolah sekiranya siswa dapat menjaga sikap dengan guru ataupun pegawai sekolah, sekiranya berlaku sesuai pantasnya kepada guru, karena bagaimanapun juga guru adalah orang tua disekolah. Lingkungan bermain yang dalam tanda kutip bebas juga dapat mempengaruhi kepribadian siswa, misalnya siswa masih berumur belasan tahun bergaul dengan orang yang lebih dewasa. Siswa tersebut secara umur kurang bisa menyaring mana yang sekiranya baik untuk diambil dan mana yang kurang baik untuk diambil. Tentunya lingkungan keluarga juga mempunyai pengaruh yang besar bagi siswa, didikan orang tua khususnya dalam membentuk kepribadian anaknya, cara memperhatikan dan pemberian kasih sayang sesuai yang dibutuhkan anaknya. 


\section{Solusi Peran Yang Membentuk Kepribadian Siswa}

Solusi atas kasus bullying siswa terhadap guru sebenarnya dapat ditemukan titik terang dengan melibatkan beberapa pihak mulai dari guru, siswa, orang tua dan teman sekolah. Setiap pihak mempunyai peran masing-masing dalam membentuk kepribadian pelaku bullying, karena pada dasarnya kontek kebebasan berpendapat atau aspirasi mereka dapat dituangkan melalui wadah yang didalamnya terdapat pihak-pihak tersebut. Terkadang niat penuangan aspirasi tersebut setiap individu berbeda-beda caranya, sebenarnya mereka ingin mendapatkan perhatian yang lebih, hanya saja cara yang digunakan pelaku adalah cara yang salah.

Semua pihak yang terlibat sebaiknya lebih dalam lagi berintropeksi diri, supaya tindakan yang demikian tidak terulang lagi, karena pada dasarnya sekolah adalah tempat untuk menimba ilmu, bukan tempat untuk nongkrong. Demi nama baik sekolah dan segala unsur didalamnya maka alangkah lebih baiknya untuk selalu menjaga tingkah laku personal dengan dasar ketentraman bersama.

\section{Daftar Pustaka}

https://amp.kompas.com/nasional/read/2016/08/13/16063041/perlukah.pp.perlind ungan.guru.

https://m.ayobandung.com/read/2019/02/13/44987/viralnya-kasus-bullying-siswa$\underline{\text { terhadap-guru-potret-buram-dunia-pendidikan }}$

Dewantara, Agustinus. "Filsafat Moral (Pergumulan Etis Keseharian Hidup Manusia)." (2017). 